\title{
Isolation, Molecular, and Pathological Characterization of Infectious Bursal Disease Virus among Broiler Chickens in Morocco
}

\author{
Maryame Cheggag* ${ }^{1,2}$, Khalil Zro $^{3}$, Mariem Terta ${ }^{4}$, Siham Fellahi ${ }^{2}$, Mohamed Mouahid $^{5}$, Mohammed El Houadfi $^{2}$, \\ Ghizlane Sebbar ${ }^{3}$ and Faouzi Kichou ${ }^{2}$ \\ ${ }^{1}$ Division of Pharmacy and Veterinary Inputs, ONSSA, Rabat, Morocco \\ ${ }^{2}$ Hassan 2nd Institute of Agronomy and Veterinary Medicine, Rabat, Morocco \\ ${ }^{3}$ Biopharma, Rabat, Morocco \\ ${ }^{4}$ Faculty of Sciences and Techniques Mohammedia, Hassan II University, Casablanca, Morocco \\ ${ }^{5}$ Mouahid's Veterinary Clinic, Temara, Morocco \\ "Corresponding author's Email: cheggagmaryame@ gmail.com; ORCID: 0000-0002-8093-0149
}

Received: 20 Jul. 2020

Accepted: 24 Aug. 2020

\begin{abstract}
Infectious bursal disease (IBD) is a contagious viral disease of young chickens that causes immunosuppression, mortality, and growth retardation. This pathology has severely affected the Moroccan poultry industry. The objective of the present study was the isolation, molecular characterization, and histopathology examinations of infectious bursal disease virus collected from 49 suspected farms from different regions of the country from 2013 to 2016 . The real-time PCR results indicated that 41 out of 49 farm cases were found positive with a prevalence of $41 \%$ for classical virulent IBD virus (IBDV) and 59\% for very virulent IBDV (vvIBDV). Pathological examinations showed the presence of two types of lesions, including acute to subacute lesions with a prevalence of $86 \%$, and the subchronic to chronic lesions with a prevalence of $14 \%$. The nucleotide and deduced amino acid sequences for the hypervariable region of VP2 for 7 vvIBDVs were compared to worldwide IBDV isolates and the findings suggested that it belonged to a group of very virulent strains. Phylogenetically, all the Moroccan vvIBDV field isolates were grouped in the same cluster with Malaysian and European vvIBDV isolates. This report demonstrated the continuous circulation of vvIBDV in commercial poultry farms in Morocco since 2013.
\end{abstract}

Keywords: Histological investigations, Infectious bursal disease virus, Phylogeny, Morocco, Virulent infectious bursal disease virus, VP2

\section{INTRODUCTION}

Infectious bursal disease (IBD) is an acute and highly contagious viral and immunosuppressive disease of young chickens imposing severe economic losses to the poultry industry (Sassia et al., 2017). Infectious bursal disease virus (IBDV), member of the genus Avibirnavirus in family Birnaviridae, is a non-enveloped, icosahedral virus with a diameter of 60-65 nm (Nick et al., 1976; Özel and Gelderblom, 1985; Mosley et al., 2017; Pikula et al., 2018). There are two serotypes of IBDV, namely serotypes 1 and 2; the strains of serotype 1 can also be categorized as classical virulent IBDV (cvIBDV), antigenic variant IBDV (avIBDV), attenuated IBDV (atIBDV), and very virulent IBDV (vvIBDV, Jeon et al., 2008; Tsai et al., 2012; Cheggag et al., 2018). The IBDV possesses a bisegmented genome, namely segments A and B. Segment A encodes two open reading frames for the nonstructural protein, including structural protein VP5 (17 $\mathrm{kDa})$ and the polyprotein pVP2-VP4-VP3 (109 kDa). In contrast, segment $\mathrm{B}$ encodes for the RNA-dependent RNA polymerase VP1 $(90 \mathrm{kDa})$. The hypervariable region (HVR) displaying high amino acid variability of the VP2 antigens of IBDV is located on the amino acid residues 206-350 (Bayliss et al., 1990). This region is responsible for antigenic tissue-culture adaptation, variation, and is partly in charge of viral virulence (Escaffre et al., 2013). The clinical or subclinical prevalence of IBD is found in chickens during their first three weeks of age leading to immunosuppression. 
The phase of chickens' immunosuppression is associated with their age (Sellaoui et al., 2012). The macroscopic characteristic lesions related to this disease consist of enlargement, orange discoloration of kidneys, and dehydration of the muscles with ecchymotic hemorrhages (Brugere-Picoux, 2015). The IBDV spreads in the bursa of Fabricius (BF) by deteriorating its lymphoid structure, and cause different lesion types depending on the virulence of the strains and immune status of the affected chicken (Jungbaeck and Nutolo, 2001; Juranová et al., 2001). These lesions generally induced immunosuppression resulting in the appearance of secondary infections and weak production performances. The principal characteristics of lesions in the bursa are the cystic formation of follicles, follicular atrophy, bursal hemorrhage, and mild to severe lymphoid depletion in follicles (Mazariegos et al., 1990; Madej et al., 2013). This infection was first described in 1962 in the USA (Cosgrove, 1962) and since then it has been known as one of the most economical important pathologies affecting the poultry industry worldwide. The emergence of various IBD forms in the USA or vvIBDV forms in Europe, Africa, Asia, and other countries has induced severe problems for IBD control and prevention since instances of classical IBDV strains was reported in vaccinated chickens or chicks with maternal antibodies levels for which they were supposed to be IBD resistant (Chettle et al., 1989; Van Den Berg et al., 1991; Snyder 2007; Kasanga et al., 2007). In Morocco, the IBD was determined for the first time in poultry flocks in 1977 (Tahiri et al., 2011). This pathology has become endemic since the high mortality and introduction of very virulent strains of IBDV in 1991 (Bouzoubaa et al., 1992; Kichou et al., 1999). Therefore, the current study was conducted to isolate and characterize the pathological and molecular aspects of the existing IBDV strains affecting Moroccan poultry flocks. It further aimed to describe the sequencing and phylogenetic analysis of IBDV isolates from 2013 to 2016.

\section{MATERIALS AND METHODS}

\section{Animals}

The autopsied samples were selected among dead broilers suspected of the infectious bursal disease. These broilers were from farms located in five different regions of Morocco (Souss-Massa, Fes-Meknes, CasablancaSettat, Oriental and Draa Tafilalet). Broilers were monitored by the veterinarian in farms. During the observation, the chickens were given access to water and fed ad libitum, and then cared in case of emergency. For confidentiality reasons. It was not possible to provide any data about the vaccines and the vaccination program adopted under supervising of specialist veterinarians in all studied farms.

\section{Sampling}

This study was conducted on 49 pools of bursa Fabricius collected from broiler chicken farms. The investigated samples were suspected of IBDV during the period of 2013 to 2016. Lesions reported in broilers suspected of IBDV are located primarily in the bursa of Fabricius and spleen and included hypertrophy and hemorrhage. The presence of petechiae and muscle hemorrhage were also noted in all cases. The bursal samples, taken after autopsy from broilers, were fixed in a $10 \%$ neutral buffered formalin for histological examination, and others were frozen at $-80{ }^{\circ} \mathrm{C}$ for isolation and molecular analysis.

\section{Histopathology}

The 10\% NBF-fixed bursa Fabricius from 43 farmcases were subjected to histopathological examination. They were processed in accordance with paraffin embedding standard methods. In this regard, five- $\mu$ thick sections were prepared, stained with the hematoxylin and eosin (H\&E), and examined under the light microscope (ZEISS SIGMA, Germany) for histopathological evaluation.

The investigated characteristic changes of infectious bursal disease included depletion, necrosis, hemorrhage, infiltration by inflammatory cells and/or fibrin deposit in the lymphoid follicle, Edema, congestion, hemorrhage, infiltration by inflammatory cells, fibrin deposit and/or fibrosis in the interfollicular space, presence of caseous material on the surface epithelium, as well as folding, thickening, and/or hyperplasia of the surface epithelium with or without the formation of pseudo-cysts. Microscopic lesions were recorded, and the lesion scores of 1 to 3 were assigned to the samples based on the degree of lesion severity (1: mild, 2: severe, 3 : very severe). A mean lesion score (MLS) was determined for each farmcase for comparison purposes.

\section{Development of chicken embryo fibroblast cell line}

The 9- to 11-day-old embryonated chicken eggs, belonging to the production unit of the Society for Veterinarians Biological and Pharmaceutical Production (Biopharma, Morocco) were harvested, and the embryos were taken out. The appendages and viscera were 
discarded after proper washing. In the next step, the remainder body was chopped in fine cuts by scissors, kept into specific Erlenmeyer with $50 \mathrm{ml}$ of trypsin EDTA (37 ${ }^{\circ} \mathrm{C}$ ), and stirred for 5 minutes at low speed (100 rpm). The supernatant was removed, and then $50 \mathrm{~mL}$ trypsin was added to pieces in the same Erlenmeyer, and stirred for 5 minutes (this operation was repeated twice). Trypsinized tissue was filtered with a gauze pad, and the recovered volume was tarnished in a conical tube $(50 \mathrm{ml})$. After the addition of $10 \%$ donor calf serum, the filtrate was centrifuged at $1200 \mathrm{rpm}$ for 10 minutes and the supernatant was discarded. The pellet was dissolved by adding $1 \mathrm{~mL}$ of growth medium. Afterward, cells were transferred in culture flask, and the growth media was added later (Sahare et al., 2015).

\section{Virus isolation}

The virus isolation was performed using seven suspensions of BF recognized as vvIBDV. The primary chicken embryo fibroblast (CEF) cell line was passaged when the cultured cells reached confluency of $70-80 \%$. The normal and confluent appearance of the monolayer of CEF cells after 24 hours of subculturing was used for the infection with $0.5 \mathrm{~mL}$ of filtered field IBDV. The virus suspension was overlaid uniformly over the monolayer and incubated at $37{ }^{\circ} \mathrm{C}$ for 1 hour. One flask was kept as un-inoculated control. The $5 \mathrm{~mL}$ of maintenance medium was added to each flask after a 1-hour incubation. Flasks were incubated at $37{ }^{\circ} \mathrm{C}$ in $5 \% \mathrm{CO} 2$ for 48 hours. The cell monolayer was examined twice daily under an inverted microscope for cytopathic effects (CPEs, Sahare et al. 2015). The embryonated chicken eggs were cultivated using $0.2 \mathrm{~mL}$ of virus suspension inoculated in 9- to 11 day-old embryonated chicken eggs by the chorioallantoic membrane route. The eggs were incubated for 5 days in the incubator (Sahare et al., 2015). The embryonated chicken eggs were chilled on the fifth day of postinoculation. Lesions on the embryo were observed, and then the appendages and viscera of the embryo were removed and mixed with the allantoic fluid harvested and arranged in the conical tube $(50 \mathrm{ml})$. Afterward, the mixture was centrifuged at $12000 \mathrm{rpm}$ for 10 minutes and stored at $-80{ }^{\circ} \mathrm{C}$. The IBDV challenge strain (Biopharma, Morocco) was used as a reference strain for this isolation study.

\section{Purity of isolates}

It was necessary to evaluate the purity of the seven vvIBDV isolates by real-time RT-PCR before sequencing. To this end, nucleic acids extracted from the isolates were tested for the presence of others avian viruses , including infectious bronchitis virus (IBV, Meir et al., 2010), Newcastle disease virus (NDV, Wise, et al., 2004), and avian influenza virus (AIV, Spackman et al., 2002).

\section{Real-time PCR}

Viral RNA was extracted from $150 \mu 1$ of suspension of the vvIBDV isolates on chicken embryo fibroblast cell line and embryonated chicken eggs using the Nucleospin RNA Virus Extraction kit (Machery-Nagel, Germany) following the manufacturer's instructions. The extracted RNA was eluted in $50 \mu 1$ of nuclease-free water and stored at $-80^{\circ} \mathrm{C}$ until use. The real-time PCR (RT-PCR) targeted VP5/VP2 overlapping region of segment A using the specific primers and probes (Tomás et al., 2012) designed by Bioneer, Korea, as described by Gonzalo et al. (2012). It could detect and discriminate vvIBDV strains from nonvvIBDV strains. The RT-PCR protocol was described by Cheggag et al. (2018).

\section{Complementary DNA synthesis for VP2-HVR}

In the first step, cDNA was synthesized by the Tetro cDNA Synthesis kit (Bioline, Germany) and specific primers for the amplification of VP2-HVR at $97^{\circ} \mathrm{C}$ for 5 minutes according to the manufacturer's instructions. In the second step, the 5x RT buffer, RT plus RT inhibitor were added and the RT was performed at $25^{\circ} \mathrm{C}$ for 10 minutes, then $45^{\circ} \mathrm{C}$ for 60 minutes followed by $85^{\circ} \mathrm{C}$ for 5 minutes. The synthesized cDNAs were used as templates for PCR.

\section{PCR nucleotide sequencing of VP2-HVR}

The IBDV VP2-HVR was detected by PCR using the primer pair 743-F (5'-GCCCAGAGTCTACACCAT-3') and 743-R (5'-CCCGGATTATGTCTTTGA-3'), as suggested previously by Nwagbo et al. (2016). The PCR was performed on Verity thermocycler (Applied Biosystems) using HS MyTaq DNA polymerase, Bioline kit (Bioline, United Kingdom), following thermocycling conditions of $95^{\circ} \mathrm{C}$ for 120 seconds, 35 cycles of $47^{\circ} \mathrm{C}$ for 30 seconds, $72^{\circ} \mathrm{C}$ for 30 seconds, and $72^{\circ} \mathrm{C}$ for 3 minutes. The PCR products were visualized following electrophoresis on a $1 \%$ agarose gel stained with ethidium bromide.

The PCR products were purified and sequenced at Molecular Biology and Functional Genomics Platform of National Centre for Scientific and Technical Research (Morocco) on an ABI 3130xl Genetic Analyzer, 16 capillary sequencers (Applied Biosystems, California, USA). The sequences were submitted to the GenBank 
database, National Center for Biotechnology Information (NCBI), and were assigned the accession numbers as shown in Table 1.

\section{Phylogenetic analysis}

The VP2 gene sequences of 7 isolates were corrected and compared with the reference sequence available in the public database (http://www.ncbi.nlm.nih.gov/) and with available sequences deposited in GenBank (http://www.ncbi.nlm.nih.gov/Genbank) using nucleotide Basic Local Alignment Search Tool (http://www.ncbi.nlm.nih.gov/BLAST/) for nucleotide (blastn), and for an amino acid (blastp). The nucleotides and amino acids sequences were edited and aligned using the BioEdit software package and MEGA Version 6.1 (MEGA: Molecular Evolutionary Genetics Analysis). The relationship between the strains was analyzed by phylogenetic tree using MEGA program. The neighborjoining methods were used for analysis and the bootstraps were calculated with 1000 replications (Fessehaie et al., 2002; Tamura et al., 2007; Tamura et al., 2011).

\section{Statistical analysis}

The results of RT-PCR Viral RNA of suspension of the vvIBDV isolates on the Chicken Embryo Fibroblast Cell Line and Embryonated Chicken Eggs were analyzed using the IBM SPSS software, version 25. P-value less than 0.05 was considered significant. The chi-square test was used to investigate the correlation between RT-PCR results of the two different techniques used for IBDV isolation. In addition, the correlation between the severity (MLS) and type of histological changes in birds and the pathogenicity of identified IBDV from field samples was evaluated using Fisher's exact and Pearson chi-square tests.

\section{Ethical approval}

The experiment was carried out after the agreement of the Scientific and Technical Committee of BIOPHARMA taking into account the rules of ethics and animal welfare implemented by the BIOPHARMA laboratory in accordance with the norms and standards of the OIE manual. BIOPHARMA has an animal house, its premises and procedures are periodically inspected by a joint commission of the Ministry of Agriculture and Health of Morocco. Any animal presenting suffering or discomfort was euthanized according to the procedures implemented by the laboratory of Biopharma.

Table 1. Description of infectious bursal disease virus isolates included in the present study

\begin{tabular}{lcccccc}
\hline Virus isolate & flock type & $\begin{array}{c}\text { Date of } \\
\text { collection }\end{array}$ & Sample type & Origine & $\begin{array}{c}\text { Age of bird } \\
\text { (days) }\end{array}$ & $\begin{array}{c}\text { GenBank } \\
\text { accession no }\end{array}$ \\
\hline IBDV8VP2MOROCCO2015 & Broiler & 2015 & Bursa & Témara & 26 & MN241434 \\
IBDV11VP2MOROCCO2014 & Broiler & 2014 & Bursa & Témara & 26 & MN241437 \\
IBDV27VP2MOROCCO2015 & Broiler & 2015 & Bursa & El Jadida & NA* & MN241433 \\
IBDV28VP2MOROCCO2015 & Broiler & 2015 & Bursa & El Jadida & NA* & MN241438 \\
IBDV30VP2MOROCCO2015 & Broiler & 2015 & Bursa & El Jadida & NA* & MN241439 \\
IBDV41VP2MOROCCO2015 & Broiler & 2015 & Bursa & Tit Milil & 25 & MN241435 \\
IBDV40VP2MOROCCO2015 & Broiler & 2015 & Bursa & Tit Milil & 29 & MN241436 \\
\hline
\end{tabular}

* not available

\section{RESULTS}

\section{Real-time PCR}

The RT-PCR results indicated that 41 out of 49 suspected flocks were found positive with a prevalence of $41 \%$ for non-virulent cvIBDV and $59 \%$ for vvIBDV. The Threshold Cycle $(\mathrm{Ct})$ value for RT-PCR for seven isolates on $\mathrm{CEF}$ ranged from 16.31 to 25.44 , and for those on embryonated chicken eggs were in the range of 16.13 to 27.63 .

Histopathological changes
The results of the histopathological examination showed that bursas from the 35 cases of broiler chicken farms in the current study were carriers of characteristic bursal lesions that can be attributed to IBD viruses (vaccine or wild viruses). With regard to the nature of lesions and the inflammatory phase detected, two categories of affected bursas were identified, including bursas with acute to sub-acute lesions and bursas with chronic lesions.

\section{Acute to sub-acute lesions in bursa of Fabricius}


Lesions in this group of bursas included depletion, necrosis, hemorrhage, infiltration by inflammatory cells, and/or fibrin deposit in the lymphoid follicle as well as edema, congestion, hemorrhage and/or infiltration by heterophilic inflammatory cells in the inter-follicular space (Figure 1A). Among the investigated cases, 32 samples were classified in this first category. The obtained results of MLS within this category were suggestive of three subgroups of bursas. To clarify, subgroup 1 of bursas with an MLS < 2 represented $28.6 \%$ of cases. The subgroup 2 of bursas with MLS range of 2-3, and a subgroup 3 with an MLS > 3 represented in this same category $37.1 \%$ and $25.7 \%$ of cases, respectively (i.e., a total $91.4 \%$ of cases with acute to subacute bursal lesions).

\section{Sub-chronic to chronic lesions in bursa of}

\section{Fabricius}

Bursal lesions classified as chronic included interstitial thickening, lymphoid depletion, fibrosis, and folding of the surface epithelium with or without a formation of pseudocysts (Figure 1B). Bursa from all 3 cases in this category had an MLS $<2$. Among all 35 RTPCR IBDV positive farm-cases, 32 cases had acute to subacute bursal changes while only three indicated chronic changes. Within the category of farm-cases with acute bursal lesions, characterized hypervirulent and low pathogenicity IBD viruses were identified with a similar trend among different MLS sub-groups (Table 2) with a slightly higher percentage for vvIBDV, compared to subgroup cases with an MLS > 3 (6/32). However, statistical analysis (Fisher's exact test statistic; $p \geq 0.05$ ) did not show any correlation between the severity of lesions (MLS) and the pathogenicity of IBDVs characterized by RT-PCR (Table 3).

\section{Virus isolation}

The IBDV has the property of causing a specific and characteristic cytopathogenic effect (CPEs) on CEF cells. The CEF cells were examined under the microscope for CPEs (Figure 2A) indicated the presence of IBDV while checking negative controls (Figure 2B) that were free of CPEs. Concerning viral isolation in embryonated chicken eggs, the presence of IBDV was revealed by embryos with hemorrhagic traces throughout the body of the embryo, edema, vessel congestion, growth retardation, and sometimes with a greenish liver (Figure 3).

\section{Comparison between the results of two IBDV isolation techniques}

The results of Table 4 tabulating the statistical analyses indicate no correlation between the two IBDV isolation techniques $(\mathrm{p}>0.05)$.

\section{Purity of isolates.}

No positive results were obtained with any of the other avian viruses, such as NDV, IBV, and IA using RTPCR, therefore, the purity of IBDV isolates was confirmed.

\section{Phylogenetic analysis}

Sequencing was performed on the HVRs of VP2 gene of seven IBDV isolates. The nucleotide and deduced amino acid sequences (Table 5) of these IBDV isolates were blasted and compared with the reference strain sequences retrieved from GenBank from different regions of the world. Table 5 summarizes the classical and very virulent reference strains used in the present study. The phylogenetic tree revealed that the Moroccan strains were clustered into genogroup 3 regrouped very virulent strains (Figure 4). The first genogroup comprised the vvIBDV strains from different countries and formed a common branch with Moroccan strains characterized in the present study and those recently isolated by Drissi Touzani et al. (2019). However, they were clearly clustered into two distinct clusters within the group. The second genogroup included all classical IBDV strains.

\section{Molecular characterization of Moroccan infectious bursal disease virus}

The deduced amino acid sequence of the HVR (positions 222 to 428 of the VP2 protein) was determined for each of the isolates, and compared to wellcharacterized classical virulent IBDV (D78, Faragher 52/70, 2512 Winterfield, Lukertand LC 75) and vvIBDV, which was used to construct a phylogenetic tree with results similar to those obtained with the nucleotide sequences (Figure 4). The sequence identity among the Moroccan vvIBDV isolates fluctuated from $96.2 \%$ to $100 \%$. Seven Moroccan IBDV contained the genetic signature of vvIBDVs strains, specifically, A222, I242; I256, I294, S29. It is important to mention that heterogeneous variations were also detected in these isolates. 
The deduced amino acid sequence of the HVR was determined for each of the isolates and compared to wellcharacterized classical virulent IBDV isolates (F52/70 [CAA7518]), African vvIBDV isolates, vvIBDV isolates from other countries, and Moroccan vvIBDV isolates.

Four Moroccan IBDV isolates (i.e., MN241433, MN241434, MN241436, and MN241437) contained the genetic signature of vvIBDVs, specifically, A222, I256,
I294, and S299 (Figure 5). A single point mutation, resulting in a single amino acid change, was distinguished in Moroccan IBDV isolates, named MN241439, a nucleotide change resulted in a $(\mathrm{G})$ at position 225 $(\mathrm{V} \rightarrow \mathrm{G}) ; 238(\mathrm{~T} \rightarrow \mathrm{P}) ; 249(\mathrm{Q} \rightarrow \mathrm{H})$ and $353(\mathrm{~A} \rightarrow \mathrm{T})$. There were also variations in these seven isolates at amino acid $222(\mathrm{~A} \rightarrow \mathrm{T})$, in two strains of MN241433 and MN241438.
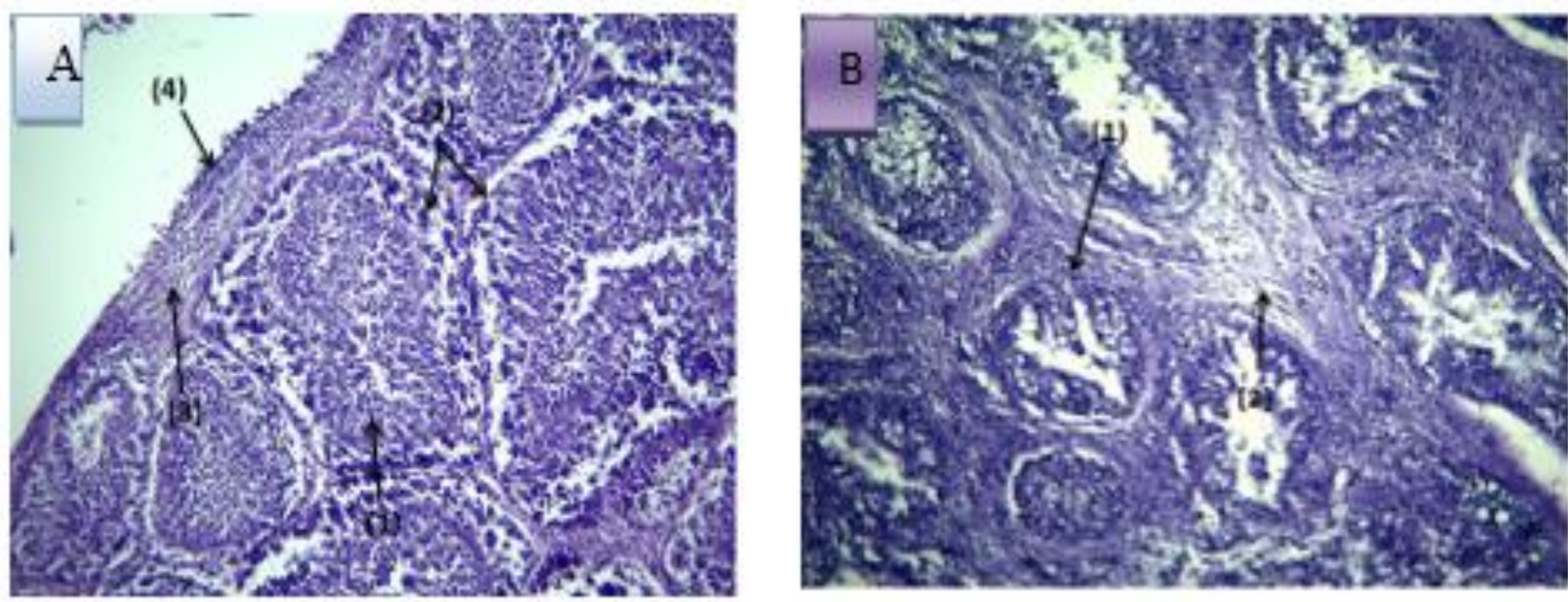

Figure 1. Histological section of the bursa of Fabricius of broiler chicken. Hematoxylin and Eosin. Bar: $168 \mu \mathrm{m}$. A: Acute to subacute lesions. Discrete lymphoid depletion (1) and slight oedema in parafollicular areas of the lymphoid follicles (2). Moderate infiltration of the surface subepithelial chorion by inflammatory cells (3) and desquamation of the surface epithelium (4). B: sub-chronic to chronic. Atrophy of lymphoid follicles with very marked lymphocyte depletion (1). Very marked thickening of the interfollicular spaces by severe fibrosis (2).
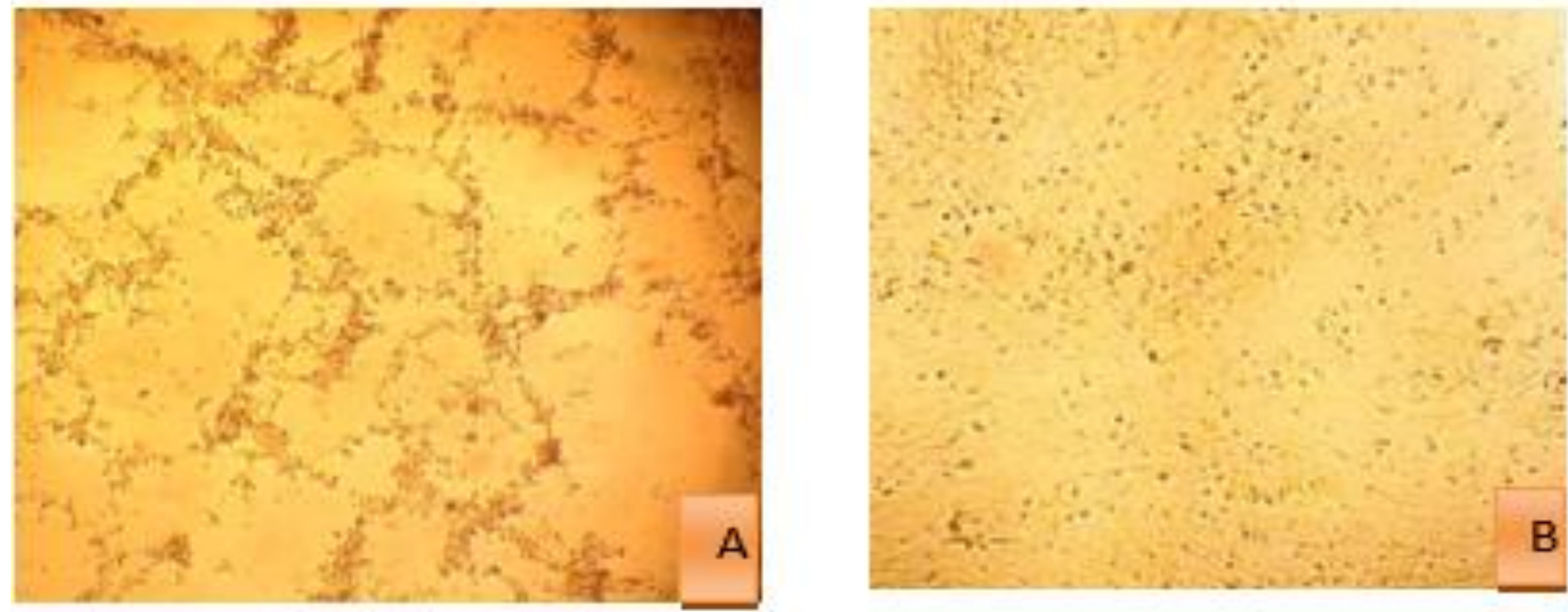

Figure 2. Adaptation of very virulent infectious bursal disease virus in primary chicken embryo fibroblast cells showing cytopathic effects after 48 hours of transfection. A: Primary chicken embryo fibroblast cells infected with very virulent infectious bursal disease virus showing prominent cytopathic effects. B: Chicken embryo Fibroblast cell line with $90 \%$ confluency. 


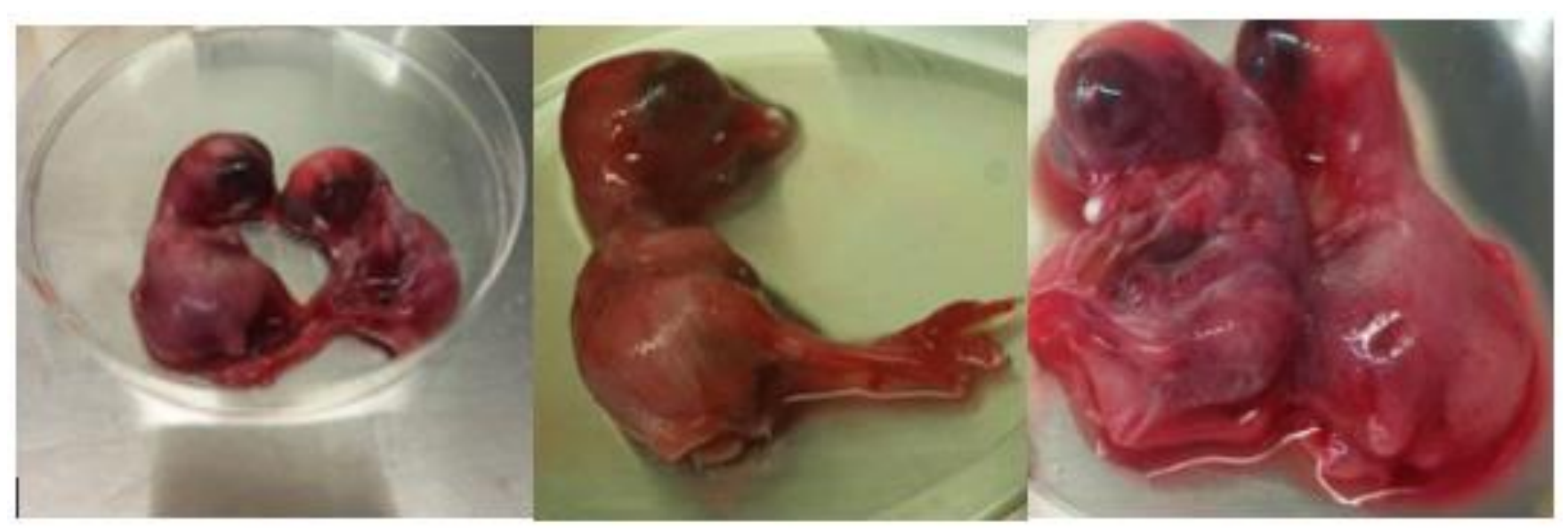

Figure 3. Lesions induced in chicken embryos infected with very virulent infectious bursal disease virus

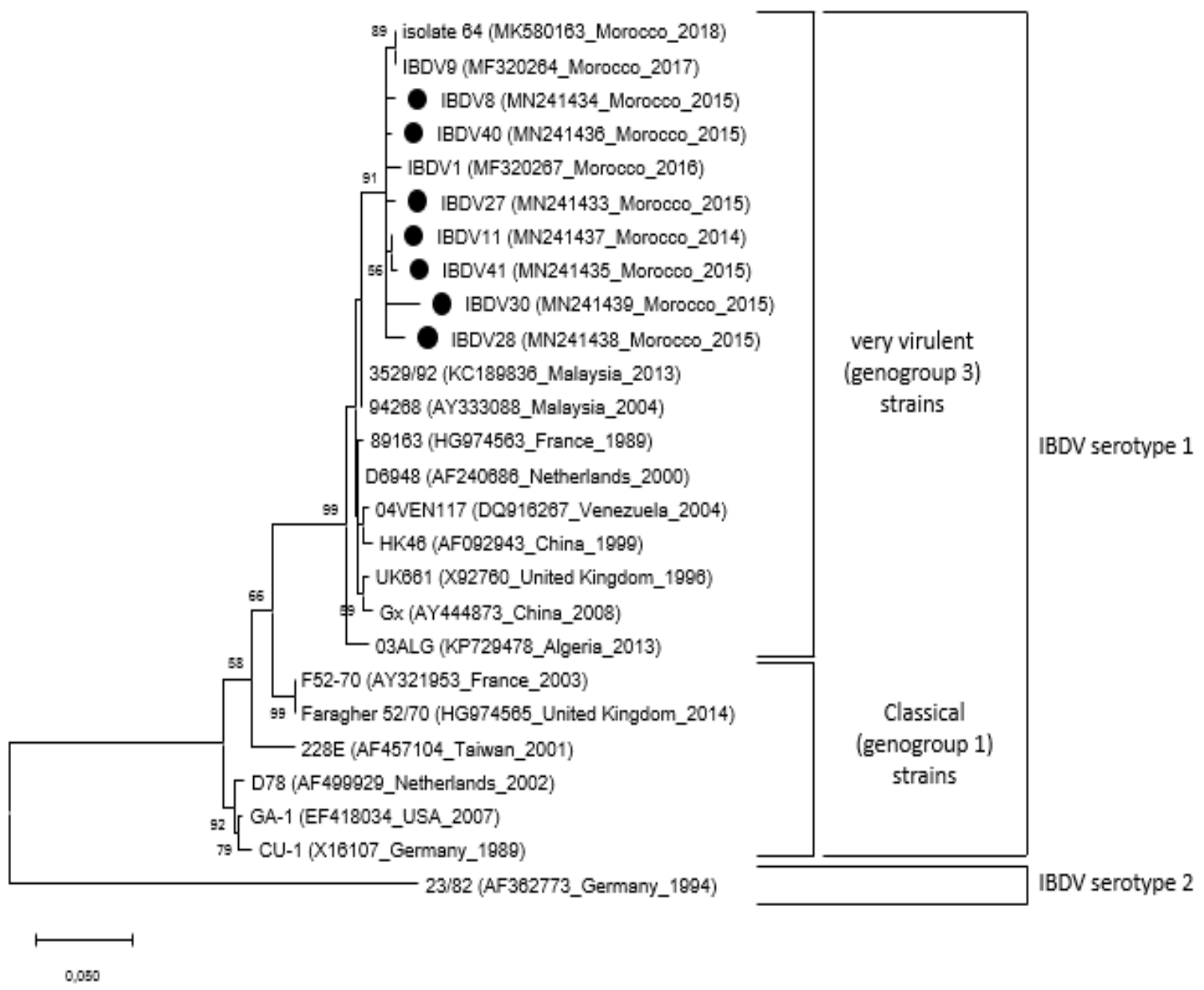

Figure 4. Phylogenetic relationships between some very virulent (genogroup 3) strains of infectious bursal disease virus. The nucleotide sequence encoding the hypervariable region of the structural proteinVP2 protein was used as a phylogenetic marker. The analysis was performed in Mega using the neighbor-joining method with 1000 bootstrap replicates. Only bootstrap values greater than 50 are shown. Four classical strains of infectious bursal disease virus serotype 1 and one strain of IBDV serotype 2 were used as outgroups. The countries of origin of the strains and the GenBank accession numbers for structural protein VP2 sequences are given in brackets after the strain names. Moroccan strains presented in this paper are shown in bold. 


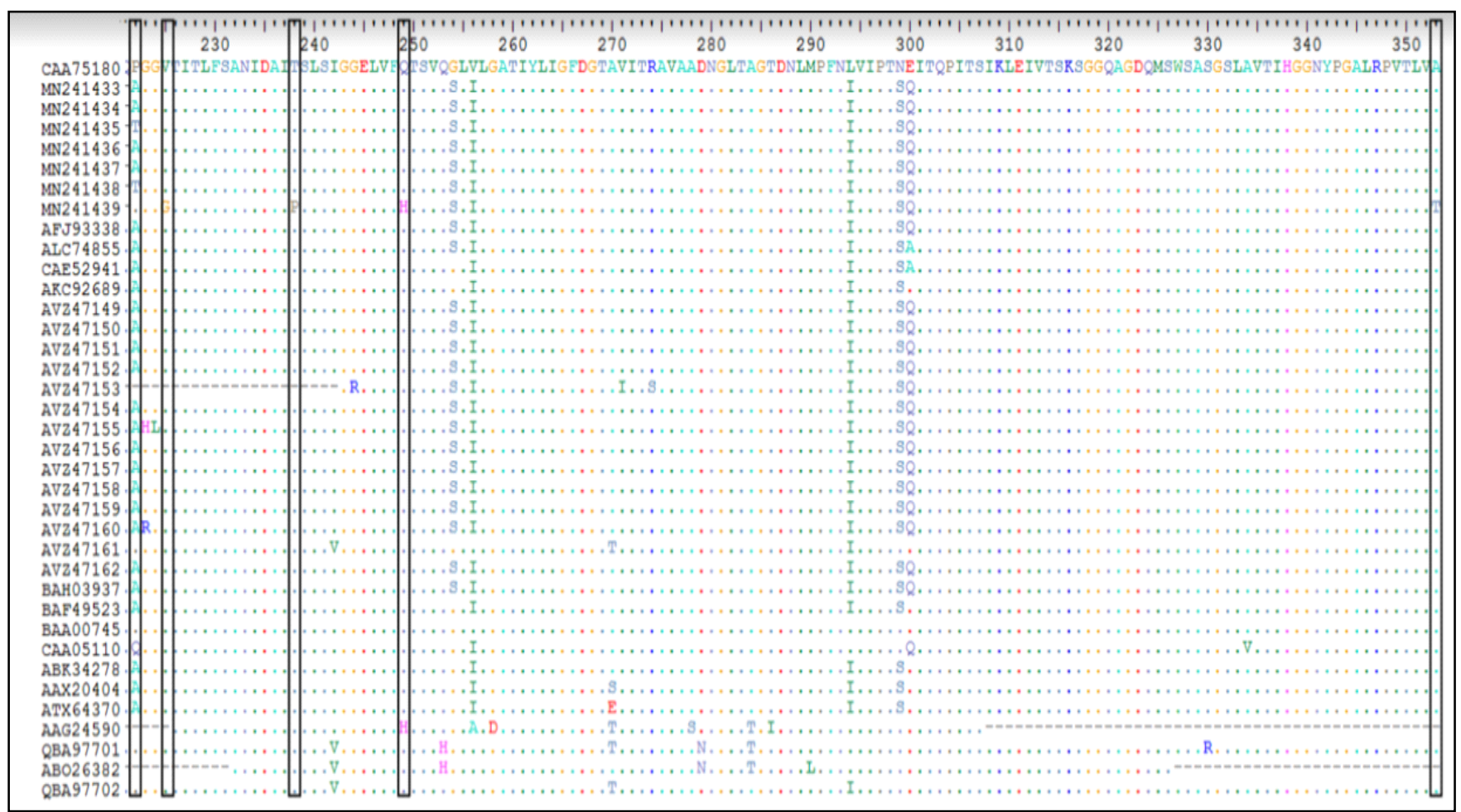

Figure 5. Amino acid sequence comparison of 35 infectious bursal disease virus strains. IBDV strains used for comparison include classical virulent IBDV isolates (F52/70 [CAA7518]), African very virulent infectious bursal disease virus isolates, very virulent infectious bursal disease virus isolates from other countries (USA, Asia), and Moroccan vvIBDV isolates

Table 2. Comparison between the results of the histopathological examination and real-time PCR from field samples of broiler chickens

\begin{tabular}{|c|c|c|c|c|c|c|c|c|}
\hline \multirow{3}{*}{ Real-time PCR results } & \multicolumn{8}{|c|}{ Histopathological lesions } \\
\hline & \multicolumn{4}{|c|}{$\begin{array}{c}\text { Aigue to sub-aigue mean lesion score } \\
\text { (MLS) }\end{array}$} & \multicolumn{3}{|c|}{$\begin{array}{c}\text { sub-chronique to chronique mean } \\
\text { lesion score (MLS) }\end{array}$} & \multirow[t]{2}{*}{ Total } \\
\hline & $<2$ & 02 to 03 & $>\mathbf{3}$ & S/total & $<2$ & 02 to 03 & $>3$ & \\
\hline Cases with very virulent infectious bursal disease virus & 5 & 5 & 6 & 16 & 2 & - & - & 18 \\
\hline $\begin{array}{l}\text { Cases with non-very virulent infectious bursal disease } \\
\text { virus }\end{array}$ & 5 & 8 & 3 & 16 & 1 & - & - & 17 \\
\hline \multirow{2}{*}{ S/total } & 10 & 13 & 9 & 32 & 3 & & & 35 \\
\hline & $(28.6 \%)$ & $(37.1 \%)$ & $(25.7 \%)$ & $(91.4 \%)$ & $(8.6 \%)$ & - & - & $(100 \%)$ \\
\hline
\end{tabular}

MLS: Mean lesion score.

Table 3. The correlation between the results of the histopathological examination and real-time PCR

\begin{tabular}{lcccc}
\hline \multirow{2}{*}{ Statical tests } & \multicolumn{4}{c}{ Chi-square tests } \\
\cline { 2 - 5 } & Value & $\begin{array}{c}\text { Degree of } \\
\text { freedom }(\mathbf{d d l})\end{array}$ & $\begin{array}{c}\text { Asymptotic signification } \\
\text { (bilateral) }\end{array}$ & $\begin{array}{c}\text { Significative. Exact } \\
\text { (bilateral) }\end{array}$ \\
\hline khi-carre of Pearson & 4.738 & 2 & 0.094 & 0.145 \\
Rapport of vraisemblance & 4.005 & 2 & 0.135 & 0.159 \\
Fisher's Exact Test & 3.99 & - & 0.296 & 0.159 \\
\hline
\end{tabular}

$\mathrm{N}$ of valid observations

43 
Table 4. The correlation between the two infectious bursal disease virus isolation techniques

\begin{tabular}{|c|c|c|c|c|}
\hline & & & \multicolumn{2}{|c|}{ Correlation } \\
\hline & & & $\begin{array}{l}\text { rRT-PCT CTs of } \\
\text { isolates by CEF }\end{array}$ & $\begin{array}{l}\text { rRT-PCT CTs of isolates by } \\
\text { Embryonated Chicken Eggs }\end{array}$ \\
\hline \multirow{6}{*}{$\begin{array}{l}\text { Rho of } \\
\text { Spearman }\end{array}$} & \multirow{3}{*}{$\begin{array}{l}\text { rRT-PCT CTs of isolates } \\
\text { by CEF }\end{array}$} & correlation coefficient & 1 & -0.536 \\
\hline & & Signficative. (bilateral) (p) & . & 0.215 \\
\hline & & $\mathrm{N}$ & 7 & 7 \\
\hline & \multirow{3}{*}{$\begin{array}{l}\text { rRT-PCT CTs of isolates } \\
\text { by Embryonated Chicken } \\
\text { Eggs }\end{array}$} & correlation coefficient & -0.536 & 1 \\
\hline & & Signficative. (bilateral) (p) & 0.215 & . \\
\hline & & $\mathrm{N}$ & 7 & 7 \\
\hline
\end{tabular}

Table 5. Infectious bursal disease virus strains used in the present study

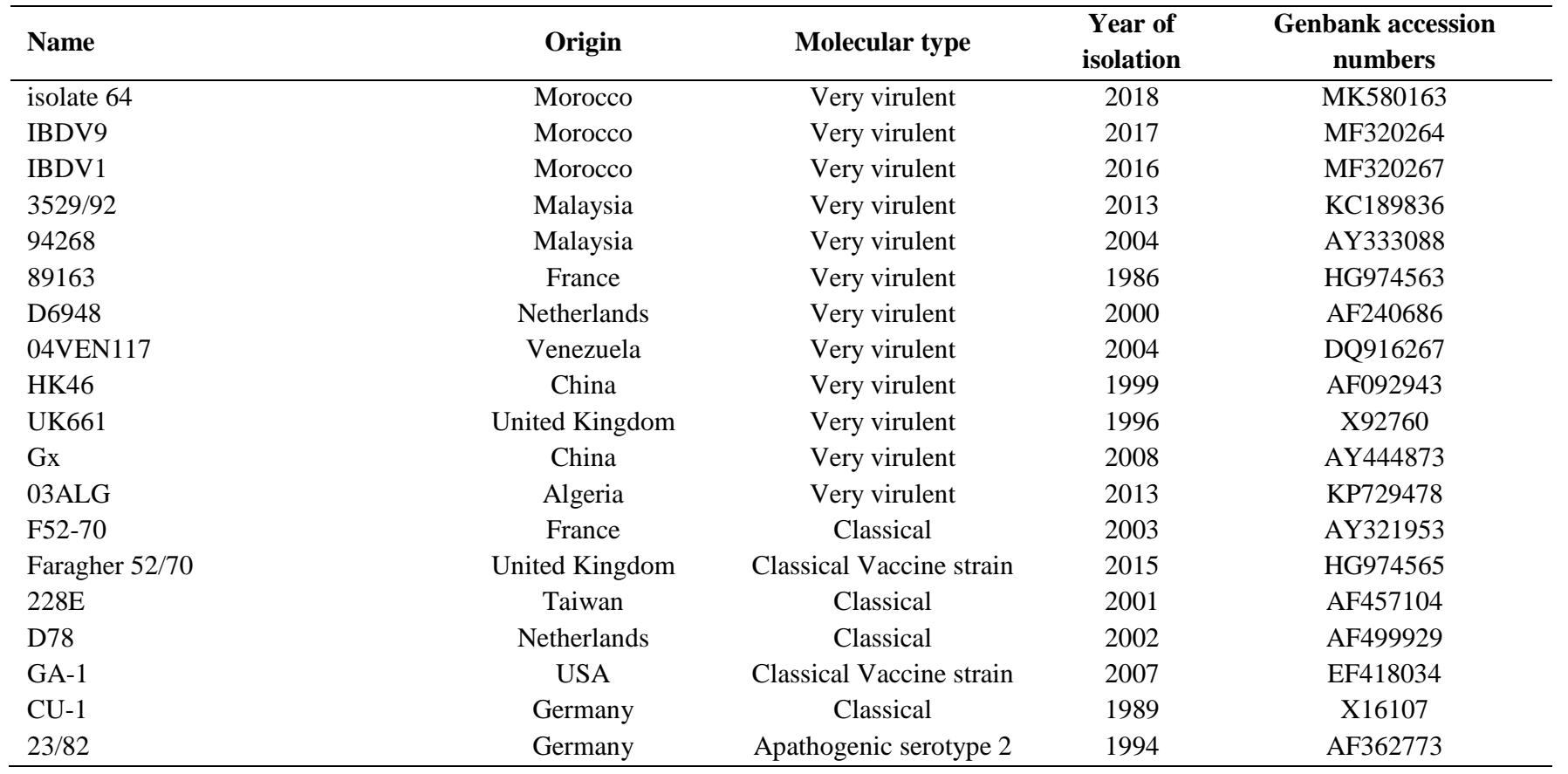

\section{DISCUSSION}

Despite the wide use of vaccines, IBD is still presenting a serious economic threat to the poultry industry in Morocco. The histological lesions caused by IBD differ in terms of severity and virulence of field IBDV strains. The vvIBDV strains induce characteristic bursal lesions with the practically total destruction of the bursal tissue more often with severe hemorrhage and/or lymphoid necrosis (Helmboldt and Garner, 1964; Cheville, 1967; Ley et al., 1983). However, the cvIBDV strains appeared to cause lesions that are somewhat difficult to differentiate from those attributed to other viruses (Jackwood and Saif, 1987). The changes found in the bursa of birds suspected of IBD in this study were mostly of acute to sub-acute types (62.85 of the cases with an MLS > 2). A total of 35 case-farms were considered suffering from severe IBD infection of which 32 case-farms were in the acute phase, and 3 case-farms were in the chronic phase. Lesions in bursas with acute to sub-acute lesions included depletion, necrosis, hemorrhage, infiltration by inflammatory cells and/or fibrin deposit in the lymphoid follicle as well as edema, congestion, hemorrhage and/or infiltration by heterophilic inflammatory cells in the inter-follicular space which constitutes a hallmark of acute IBDV infections (Gimeno and Isabel, 2013). In this category, a sub-group 1 of bursas with an MLS $<2$ represented $28.6 \%$ of cases which could be linked to an adverse effect of live vaccine viruses. Indeed, it was described that invasive intermediate and intermediate plus or hot vaccine strains retained a non- 
negligible immunosuppressive effect on the bursa (Gimeno and Isabel, 2013; Müller et al., 2012). The subgroup 2 of the bursas included $3.62 .8 \%$ of cases with severe MLS $\geq 2$ ). This severity of changes can be attributed with more certainty to the effects of the wild IBD virus. However, all changes reported in the findings of the current study could not be attributed to vvIBDV since no correlation $(p>0.05)$ was found between lesion severity and IBDV type identified by RT-PCR in field samples. Therefore, these results could only be suggestive of the challenges related to diagnosing IBD and its virulence by histopathology (Chai et al., 1999). This means that IBDV lesions can be caused by factors other than the virus strain, such as the immune status of affected chickens (Mouahid, 2006). Indeed, wild strains of IBDV were recognized to cause two forms of the disease. A clinical form was related to classical strains and hypervirulent strains causing macroscopic and histological lesions in BF with increasing degree of severity (Gimeno and Isabel, 2013; Van Den Berg, 2000), and a sub-clinical form due to the variants of IBDV. These late strains were shown to be pathogenic in broiler flocks vaccinated with conventional strains causing severe immunosuppression (Saif and Eterradossi, 2008) which would increase the susceptibility of the birds to other diseases (Ramahefarisoa, 2011; Müller et al., 2012), such as Newcastle disease, colibacillosis (Ezeibe et al., 2013), Marek's disease, and infectious anemia (Saif, 1991). Moreover, these variants were shown to cause significant damage to the bursa (Gimeno and Isabel, 2013). Bursal lesions classified as chronic in the current study included interstitial thickening, lymphoid depletion, fibrosis, and folding of the surface epithelium with or no formation of pseudocysts. Bursa from all three cases in current category had an MLS $\geq 2$ which may be considered quite severe (Gimeno and Isabel, 2013) and may be linked to hypervirulent IBDV.

Moreover, the time between the start of infection and sampling (phase of infection) was one of the most important factors which influenced the level of success in IBDV detection during an infection. As a result, it is important to sample the birds in the acute phase of infection. Thus, The IBDV can be isolated from the infected broilers during the period of 1-2 weeks (Sjaak, 2006). Severe outbreaks of IBD occurred in Morocco from 1992 to 1996 which affected $56.20 \%$ of farms practicing vaccination against IBD (Bouzoubaa K. et al., 1992; Jaouzi, 1996). In 1999, Moroccan IBDV strains were isolated and characterized for the first time. They were shown to cause high mortalities in young Specific-
Pathogen-Free chickens associated with severe macroscopic and microscopic changes of Fabricius bursa (Kichou et al., 1999). In addition, in a more recent work, the hypervirulent pathogenic strain of the IBD virus was also isolated in the country (Tahiri et al., 2011). On the basis of clinical history and histopathological examination, all broiler farms investigated in the present study were diagnosed with IBD although they were vaccinated against IBD. It should be noted that it was not possible to collect information about the type of vaccines due to confidentiality issues. Different types of IBD vaccines are commonly marketed in Morocco among which were the first-generation vaccines (live and inactivated vaccines) and the second generation (immune complex vaccines and vectorized vaccines HVT-VP2; Gimeno and Isabel, 2013).

Despite vaccination in the investigated farms, the occurrence of IBD can be explained by a set of factors, including a poor estimate of the optimal vaccination time in relation to the level of maternal anti-IBDV antibodies (Ramahefarisoa, 2011). This issue could raise the relevance of serological monitoring which made it possible to know the immune status of the flock to deduce the right time to vaccination (Boumdine, 2009). Heterogeneity of maternal antibody levels in the same vaccinated flock (Ramahefarisoa, 2011) and defective conservation and application of vaccines were other factors that can be highly incriminated in the Moroccan conditions. Moreover, the vaccine strain may not provide satisfactory protection against wild viruses due to the antigenic variability of IBDVs (Arada, 2010). Intermediate and intermediate plus or hot vaccines may not provide complete protection against infection with vvIBDV or by antigenic variants (Müller et al., 2012). However, each suspicion of antigenic variation in the field should be subjected to the isolation of the responsible viral strain and the investigation of its pathogenicity and the protection conferred by conventional vaccine strains (Etienne, 2002). No correlation was found between the techniques used for virus isolation, namely embryonated chicken eggs and primary chicken embryo fibroblast cell. The reason is that embryonated chicken eggs as a VI technique is recommended for field strains, such as the vvIBDV strain because they fail to grow or poorly grow in cell culture, and their adaptation to cell culture results in genetic changes and a loss of pathogenicity that is similar to primary chicken embryo fibroblast cell line (Sjaak, 2006). Therefore, sequencing in the current study was performed on the isolates in embryonated chicken eggs. 
The molecular characterization of vvIBDV in the diverse regions of the world was very important for understanding the trends in the evolution, spread, and field status of IBDV for effective control of IBD in chickens. In the current study, the genetic characterization of 7 vvIBDV isolates was carried out by sequencing and analysis of the HVR of the VP2 gene. The HVR, spanning amino acid residues 211 to 350 , was a major conformational and neutralizing antigenic domain. Since the greatest differences among serotype-1 strains of IBDV occurred in this part of the genome, the nucleotide and deduced amino acid sequences of this region were widely used for diagnozing and typing as a variant, classic, or very virulent (Jackwood and Sommer, 1999).

The nucleotide sequence spanning the HVR of 7 vvIBDV isolated in this study were compared to the genome sequences available in PubMed (Classical IBDV strains [D78, Faragher 52/70, 2512 Winterfield, Lukertand LC 75]) and vvIBDV strains isolated in different countries. Generally, the IBDV strains were grouped within one of three major genogroups, namely genogroup 1 (predominantly classical), genogroup 2 (predominantly variant), and genogroup 3 (predominantly vvIBDV pathotype or vvIBDV reassortant, Van Den Berg et al., 2004). Based on the results illustrated in the phylogenetic tree, the IBDV strains isolated in this study were classified in genogroup 3 (predominantly vvIBDV). Overall, the nucleotide sequence similarity of the VP2 gene among Moroccan isolates was between $96.2 \%$ and $100 \%$ (Drissi Touzani et al., 2019). The deduced amino acid sequence of the HVR of VP2 was determined and compared to different strains of vvIBDVs and a vaccine strain (Faragher 52/70). The analyzed HVR included 134 amino acid residues from positions 220 to 354 of the VP2 protein. The phylogenetic tree revealed that all the Moroccan vvIBDV field isolates were grouped in the same cluster with vvIBDV from Nigerian and Ethiopian isolates, which may indicate their ancestral relationships. It was not unexpected to discover that the Moroccan IBDV isolates were phylogenetically close to isolates from Africa due to exchanges between the African countries. It is possible that the vvIBDV strains were introduced into Morocco from neighboring countries. In addition, it is also likely that the vvIBDV has come from a more distant source due to the annual importation of huge numbers of chickens from all over the world to Morocco. The amino acid characteristic of vvIBDVs (222A, 256I, 294I and 299S; Brown et al., 1994 ; Eterradossi et al., 1999) were detected in the four analyzed vvIBDVs (i.e., MN241433, MN241434, MN241436, and MN241437). Mutations were observed in the conserved regions/positions considered exclusive to vvIBDVs. Two strains of MN241433 and MN241438 contained a substitution mutation in amino acid $222(\mathrm{~A} \rightarrow \mathrm{T})$ indicating that alanine at this position was not a unique characteristic of vvIBDVs (Parede, 2003; Jackwood and Sommer-Wagner, 2007). The HVR of VP2 contains two major and two minor hydrophilic regions (Azad et al., 1987; Van Den Berg et al., 1996). The hydrophilic peaks are located at amino acids 210 to 225 (peak A), amino acids 247-254 (minor peak 1), amino acids 281-292 (minor peak 2), and amino acids 312 to 324 (peak B, Azad et al., 1987; Van Den Berg et al., 1996). These regions are located at the outer part or projection domain of the viral capsid (Coulibaly et al., 2005). In addition to amino acid sequence differences between the studied strains and vaccine strain Faragher 52/70, two substitution mutations were found in hydrophilic regions in a key epitope in the VP2 capsid at positions of single point mutations. This issue induced single amino acid changes which were detected in MN241439 isolates, firstly, a nucleotide change resulted in a $(\mathrm{G})$ at position $225(\mathrm{~V} \rightarrow \mathrm{G}) 1$ in the major hydrophilic peak region $\mathrm{A}$, and secondly, $249(\mathrm{Q} \rightarrow \mathrm{H}) 1$ in the minor hydrophilic peak region 1 . The antigenicity of IBDV depended on the structural conformation of the major hydrophilic peaks A and B of the VP2 HVR variable region (Schnitzler et al., 1993), so changes in one or both of them could respectively lead to the emergence of either an antigenically variant serotype 1 strain or of a new serotype (Van Den Berg and Meulemans, 1991; Mardassi et al., 2004; Jackwood and Sommer-Wagner, 2011). The substitution mutation in the minor hydrophilic peak at a position of 248 to 252 was considered to influence IBDV antigenicity, as well (Eterradossi et al., 1999). Furthermore, there were two changes located outside the previously described hydrophilic regions of VP2: 238 $(\mathrm{T} \rightarrow \mathrm{P})$ and $353(\mathrm{~A} \rightarrow \mathrm{T})$. These substitution mutations, influencing the antigenicity of IBDV, made the prediction of changes in IBDV antigenicity highly unreliable in case the sequence data is the only factor to consider (Durairaj et al., 2011).

\section{CONCLUSION}

In conclusion, the current study and previous reports indicated a very virulent infectious bursal disease virus as the main cause of substantial economic losses in the poultry industry. The RT-PCR and histopathological data confirmed that the hyper-virulent form of infectious bursal disease virus continued to cause serious problems for 
Moroccan chicken breeders despite the vaccination. The seven very virulent infectious bursal disease virus clustered phylogenetically with very virulent infectious bursal disease virus from Africa (Nigeria and Ethiopia). Hypervariable region VP2 sequences were responsible for the determination of antigenicity and pathogenicity of the infectious bursal disease virus. The mutations in Hypervariable region were noticed in our isolates, especially in major hydrophilic peak region $\mathrm{A}$ and in the minor hydrophilic peak region 1 . Therefore, the amino acid changes in this hydrophic region could affect these characteristics of very virulent infectious bursal disease virus strains and the control of the disease in the future.

\section{DECLARATIONS}

\section{Funding}

This study was conducted within the framework of a collaborative agreement between Institute of Agronomy and Veterinary Medicine, Rabat, Morocco and Biopharma, Rabat, Morocco.

\section{Competing interests}

All authors declare no competing interest.

\section{Consent to publish}

Not applicable.

\section{Availability of data and materials}

The manuscript contains all datasets generated and/or analyzed in the current study.

\section{Authors' contributions}

The conceptualization of this paper was carried out by Maryame CHEGGAG, Khalil ZRO, Mohamed MOUAHID, Mohammed EL HOUADFI, Ghizlane SEBBAR, Siham FELLAHI, and Faouzi KICHOU. The formal analysis was performed by Maryame CHEGGAG, Khalil ZRO, Meriam Tarta, Ghizlane SEBBAR, Siham FELLAHI, and Faouzi KICHOU. Maryame CHEGGAG wrote the first draft of the manuscript. Faouzi KICHOU, Ghizlane SEBBAR, Meriam Tarta, and Siham Fellahi edited the manuscript prior to the submission. All authors read and approved the final manuscript.

\section{Acknowledgments}

The authors express their great thanks to sanitary mandated veterinarians supervising poultry farms in different regions in Morocco, who collaborated in sample collection and case submission.

\section{REFERENCES}

Arada AA (2010). Development of a New Vaccination Protocol against Gumboro Disease in Broilers. Thesis Diplm. Mast. EISMV. FST Dakar. available at: http://www.beep.ird.fr/collect/eismv/index/assoc/MEM109.dir/MEM10-9.pdf

Azad AA, Jagadish MN, Brown MA and Hudson PJ (1987). Deletion mapping and expression in Escherichia coli of the large genomic segment of a birnavirus. Virology, 161: 145-152. DOI: https://doi.org/10.1016/0042-6822(87)90180-2

Bayliss CD, Spies U, Shaw K, Peters RW, Papageorgiou A, Muller H and Boursnell MEG (1990). A comparison of the sequences of segment A of four infectious bursal disease virus strains and identification of a variable region in VP2. Journal of General Virology, 71: 1303-1312. DOI: https://doi.org/10.1099/00221317-71-6-1303

Boumdine K (2009). Comparative Histopathological Study of the Fabricius Bursa of Chickens Vaccinated with the Vector Vaccine Hvt-Vp2 (Vaxxitek) and Intermediate Vaccines of Gumboro Disease. IAV hasan II, Rabat, Morocco. Available at Madinat Al Irfane, BP 6202, Rabat, MAROC.

Bouzoubaa K, Mouahid M, Elhouadfi M, Amara A, Jaouzi T, Bell JG and Kichou F (1992). Severe Outbreaks of Infectious Bursal Disease in Morocco. Proceedings of the 41st Western Poultry Disease Conference, Sacramento, California, pp. 3-4. Available at IAV hasan II, Rabat, Morocco. Madinat Al Irfane, BP 6202, Rabat, MAROC.

Brown MD, Green P and Skinner MA (1994). VP2 sequences of recent European 'very virulent' isolates of infectious bursal disease virus are closely related to each other but are distinct from those of 'classical' strains. Journal of General Virology, 75: 675-680. DOI: https://doi.org/10.1099/0022-1317-75-3-675

Brugere-Picoux JVJ (2015). Manuel de Pathologie Aviaire, AFAS. PARIS. Available at:https://www.decitre.fr/livres/manuel-depathologie-aviaire-9782908014037.html

Chai YF, Meers J and Christensen NH (1999). Evaluation of serological, histological and immunocytochemical methods for the detection of infectious bursal disease virus infection in broiler flocks in New Zealand. New Zealand Veterinary Journal, 47: 175-179. DOI: https://doi.org/10.1080/00480169.1999.36138

Chettle N, Stuart JC and Wyeth PJ (1989). Outbreak of virulent infectious bursal disease in East Anglia. The Veterinary record, 125: 271-272. DOI: https://doi.org/10.1136/vr.125.10.271

Cheville NF (1967). Studies on the pathogenesis of Gumboro disease in the bursa of Fabricius, spleen, and thymus of the chicken. American Journal of Pathology, 51: 527-551. Available at: https://www.ncbi.nlm.nih.gov/pmc/articles/PMC1965379/pdf/amj pathol00263-0079.pdf

Cosgrove AS (1962). An Apparently New Disease of Chickens: Avian Nephrosis. Avian Diseases, 6: $385 . \quad$ DOI: https://doi.org/10.2307/1587909

Coulibaly F, Chevalier C, Gutsche I, Pous J, Navaza J, Bressanelli S, Delmas B and Rey FA (2005). The birnavirus crystal structure reveals structural relationships among icosahedral viruses. Cell, 120, 761-772. DOI: https://doi.org/10.1016/j.cell.2005.01.009

Drissi Touzani C, Fellahi S, Gaboun F, Fassi Fihri O, Baschieri S, Mentag R and El Houadfi M (2019). Molecular characterization and phylogenetic analysis of very virulent infectious bursal disease virus circulating in Morocco during 2016-2017. Archives 
of Virology, 164: 381-390. DOI:https://doi.org/10.1007/s00705018-4076-3

Durairaj V, Sellers HS, Linnemann EG, Icard AH and Mundt E (2011). Investigation of the antigenic evolution of field isolates using the reverse genetics system of infectious bursal disease virus (IBDV). Archives of Virology, 156: 1717-1728. DOI: https://doi.org/10.1007/s00705-011-1040-x

Escaffre O, Le Nouen C, Amelot M, Ambroggio X, Ogden KM, Guionie O, Toquin D, Muller H, Islam MR and Eterradossi N (2013). Both Genome Segments Contribute to the Pathogenicity of Very Virulent Infectious Bursal Disease Virus. Journal of Virology, 87: 2767-2780. DOI: https://doi.org/10.1128/jvi.02360-12

Eterradossi N, Arnauld C, Tekaia F, Toquin D, Le Coq H, Rivallan G, Guittet M, Domenech J, Van Den Bere TP and Skinner MA (1999). Antigenic and genetic relationships between European very virulent infectious bursal disease viruses and an early West African isolate. Avian Pathology, 28: 36-46. DOI: https://doi.org/10.1080/03079459995028

Etienne F (2002). Prevention Strategies for Gumboro Disease in SemiIndustrial Farms in the Dakar Region, Senegal. Doctoral thesis Vet. ENVT France. Available at:https://oatao.univtoulouse.fr/684/1/andro_684.pdf

Ezeibe MCO, Okoye JOA, Ogunniran TM, Animoke PC, Mbuko IJ, Nwankwo IA and Ngene AA (2013). MORTALITY RATES FROM A NIGERIAN ISOLATE OF THE INFECTIOUS BURSA DISEASE VIRUS AND PASSIVE HAEMAGGLUT(INATION ANTIBODY TITER THAT PROTECTS CHICKS AGAINST CHALLENGE WITH THE VIRUS ISOLATE. Health, 5(9): 1355-1359. DOI: https://doi.org/10.4236/health.2013.59184

Fessehaie A, De Boer,SH and Lévesque CA (2002). Molecular characterization of DNA encoding 16S-23S rRNA intergenic spacer regions and 16S rRNA of pectolytic Erwinia species. Canadian Journal of Microbiology, 48: 387-398. DOI: https://doi.org/10.1139/w02-026

Gimeno PIM (2013). IMMUNOSUPPRESIVE DISEASES OF POULTRY (Hb 2013), SERVET, Zarago, Spain. pp. 125-152.

Helmboldt CF and Garner E (1964). Experimentally Induced Gumboro Disease (IBA). Avian Diseases, 8: 561. DOI: https://doi.org/10.2307/1587944

Jackwood DH and Saif YM (1987). Antigenic Diversity of Infectious Bursal Disease Viruses. Avian Diseases, 31: 766. DOI: https://doi.org/10.2307/1591028

Jackwood DJ and Sommer SE (1999). Restriction Fragment Length Polymorphisms in the VP2 Gene of Infectious Bursal Disease Viruses from outside the United States. Avian Diseases, 43: 310. DOI: https://doi.org/10.2307/1592622

Jackwood DJ and Sommer-Wagner S (2007). Genetic characteristics of infectious bursal disease viruses from four continents. Virology, 365: 369-375. DOI: https://doi.org/10.1016/j.virol.2007.03.046

Jackwood DJ and Sommer-Wagner S.E (2011). Amino acids contributing to antigenic drift in the infectious bursal disease Birnavirus (IBDV). Virology, 409: 33-37. DOI: https://doi.org/10.1016/j.virol.2010.09.030

Jaouzi T (1996). Quelques données épidémiologiques sur la forme sévère de la maladie de Gumboro au Maroc, Janvier 1991-Avril 1993. Available at IAV hasan II, Rabat, Morocco. Madinat Al Irfane, BP 6202, Rabat, MAROC

Jeon WJ, Lee EK, Joh SJ, Kwon Jhun, Yang CB, Yoon YS and Choi KS (2008). Very virulent infectious bursal disease virus isolated from wild birds in Korea: Epidemiological implications. Virus Research, 137 : 153-156. DOI: https://doi.org/10.1016/j.virusres.2008.06.013

Jungbaeck C and Nutolo S (2001). The degres of bursa damage as a possible parameter to define the virulence of IBDV vaccine strain. In Proceeding II. International Symposium on infectious bursal didsease and chicken infectious anaemia; Rauischholzhause; Germany, pp. 460-474.

Juranová R, Nguyen Nga THI, Lkulíková and Jurajda V (2001). Pathogenicity of czech isolates of infectious bursal disease virus. Acta Veterinaria Brno, 70: 425-431. Available at:https://actavet.vfu.cz/media/pdf/avb_2001070040425.pdf

Kasanga CJ, Yamaguchi T, Wambura PN, Maeda-Machang'u AD, Ohya $\mathrm{K}$ and Fukushi $\mathrm{H}$ (2007). Molecular characterization of infectious bursal disease virus (IBDV): Diversity of very virulent IBDV in Tanzania. Archives of Virology, 152: 783-790. DOI: https://doi.org/10.1007/s00705-006-0898-5

Kichou F, El Youssoufi G, Bikour H, Jaouzi T and Benazou H (1999). Isolation, identification and pathogenicity of Moroccan field isolation of infectious bursal disease virus. In Preceeding of the forty-eighth Western Poultry Disease Conference, pp. 119-121. Available at IAV hasan II, Rabat, Morocco. Madinat Al Irfane, BP 6202, Rabat, MAROC.

Ley DH, Yamamoto R and Bickford AA (1983). The Pathogenesis of Infectious Bursal Disease: Serologic, Histopathologic, and Clinical Chemical Observations. Avian Diseases, 27: 1060. DOI: https://doi.org/10.2307/1590207

Madej JP, Chrząstek K, Piasecki T and Wieliczko A (2013). New Insight into the Structure, Development, Functions and Popular Disorders of Bursa Fabricii. Anatomia, Histologia, Embryologia, 42: 321331. DOI: https://doi.org/10.1111/ahe.12026

Mardassi H, Khabouchi N, Ghram A, Namouchi A and Karboul A (2004). A Very Virulent Genotype of Infectious Bursal Disease Virus Predominantly Associated with Recurrent Infectious Bursal Disease Outbreaks in Tunisian Vaccinated Flocks. Avian Diseases, 48: 829-840. DOI: https://doi.org/10.1637/7210052004r

Cheggag M, Zro K, Sebbar G, Rahmatallah N, Mouahid M, EL Houadfi M and Kichou F (2018). Diagnosis of Clinical Cases of Infectious Bursal Disease Using a Modified Rapid Taq Man-MGB RealTime RT-PCR Assay. Journal of Agricultural Science and Technology A, 8: 230-238. https://doi.org/10.17265/2161$6256 / 2018.04 .006$

Mazariegos LA, Lukert PD and Brown J (1990). Pathogenicity and Immunosuppressive Properties of Infectious Bursal Disease 'Intermediate' Strains. Avian Diseases, 34: 203. DOI: https://doi.org/10.2307/1591353

Meir R, Maharat O, Farnushi Y and Simanov L (2010). Development of a real-time TaqMan ${ }^{\circledR}$ RT-PCR assay for the detection of infectious bronchitis virus in chickens, and comparison of RT-PCR and virus isolation. Journal of Virological Methods, 163: 190-194. DOI: https://doi.org/10.1016/j.jviromet.2009.09.014

Mosley Y-YC, Wu CC and Lin TL (2017). Infectious bursal disease virus as a replication-incompetent viral vector expressing green fluorescent protein. Archives of Virology, 162: 23-32. doi: https://doi.org/10.1007/s00705-016-3066-6

Mouahid M (2006). Evolution of the Gumboro Virus in Morocco, The white Book of Gumboro Disease.

Müller H, Mundt E, Eterradossi N and Islam MR (2012). Current status of vaccines against infectious bursal disease. Avian Pathology, 41: 133-139. DOI: https://doi.org/10.1080/03079457.2012.661403

Nick H, Cursiefen D and Becht H (1976). Structural and growth characteristics of infectious bursal disease virus. Journal of Virology, 18: 227-234. Available at:https://jvi.asm.org/content/jvi/18/1/227.full.pdf

Nwagbo IO, Shittu I, Nwosuh CI, Ezeifeka GO, Odibo FJC, Michel LO and Jackwood DJ (2016). Molecular characterization of field infectious bursal disease virus isolates from Nigeria. Veterinary World, 9: 1420-1428. DOI: https://doi.org/10.14202/vetworld.2016.1420-1428 
Özel M and Gelderblom H (1985). Capsid symmetry of viruses of the proposed Birnavirus group. Archives of Virology, 84: 149161.DOI: https://doi.org/10.1007/BF01378968

Pikuła A, Lisowska A, Jasik A and Śmietanka K (2018). Identification and assessment of virulence of a natural reassortant of infectious bursal disease virus. Veterinary Research, p. 49. DOI: https://doi.org/10.1186/s13567-018-0586-y

Parede LH, Sapats S, Gould G, Rudd M, Lowther S and Ignjatovic J (2003). Characterization of infectious bursal disease virus isolates from Indonesia indicates the existence of very virulent strains with unique genetic changes, 9457: 37-41. DOI: https://doi.org/10.1080/0307945031000154116

Ramahefarisoa RM (2011). Factors Influencing the Humoral Immune Response Following Vaccination with a Live Vaccine against Gumboro Disease in Broiler Chickens. M.Sc Univers. Montréal. Available at:https://papyrus.bib.umontreal.ca/xmlui/bitstream/handle/1866/5 750/Ramahefarisoa Rondro 2011 memoire.pdf?sequence $=4$ \&isA llowed =y

Sahare AA, Bedekar MK, Jain SK, Singh A, Singh S and Sarkhel BC (2015). Inhibition of Infectious Bursal Disease Virus by Vector Delivered SiRNA in Cell Culture. Animal Biotechnology, 26: 5864. DOI: https://doi.org/10.1080/10495398.2014.886584

Saif YM (1991). Immunosuppression induced by infectious bursal disease virus. Veterinary Immunology and Immunopathology, 30: 45-50. DOI: https://doi.org/10.1016/0165-2427(91)90007-Y

Eterradossi N and Saif Y (2008). Infectious Bursal Disease. In: Diseases of Poultry., Iowa: Blackwell Publishing, pp. 185-208.

Sassia S, Nadir A and Ismahane L (2017). Diagnosis of chicken Gumboro disease by histopathological study of the bursa of Fabricius. REDVET Rev, vol. $18 \mathrm{~N}^{\circ}$ 9. Available at: https://www.redalyc.org/pdf/636/63653009044.pdf

Schnitzler D, Bernstein F, Muller H and Becht H (1993). The genetic basis for the antigenicity of the VP2 protein of the infectious bursal disease virus. Journal of General Virology, 74: 1563-1571. DOI: https://doi.org/10.1099/0022-1317-74-8-1563

Sellaoui S, Alloui N, Mehenaoui S and Djaaba S (2012). Evaluation of Size and Lesion Scores of Bursa Cloacae in Broiler Flocks in Algeria.

Sjaak J (2006). The Diagnostic Technique Applied to IBDV Control., The White Book of Gumboro Disease. Available at IAV hasan II, Rabat, Morocco. Madinat Al Irfane, BP 6202, Rabat, MAROC.

Snyder DB (2007). Changes in the field status of infectious bursal disease virus. DOI: https://doi.org/10.1080/03079459008418695

Spackman E, Senne DA, Myers TJ, Bulaga LL, Garber LP, Perdue ML, Lohman K, Daum LT and Suarez DL (2002). Development of a real-time reverse transcriptase PCR assay for type A influenza virus and the avian $\mathrm{H} 5$ and $\mathrm{H} 7$ hemagglutinin subtypes. Journal of Clinical Microbiology, 40: 3256-3260. DOI: https://doi.org/10.1128/JCM.40.9.3256-3260.2002

Tahiri F, Id Sidi Yahia K, Kichou F, Attrassi B, Elharrak EM, Kadiri A and Bengoumi D (2011). Pathotypic and molecular characterization of virulent strain of infectious bursal disease virus in Morocco.

Tamura K, Dudley J, Nei M and Kumar S (2007). MEGA4: Molecular Evolutionary Genetics Analysis (MEGA) software version 4.0. Molecular Biology and Evolution, 24: 1596-1599. DOi: https://doi.org/10.1093/molbev/msm092

Tamura K, Peterson D, Peterson N, Stecher G, Nei M and Kumar S (2011). MEGA5: Molecular evolutionary genetics analysis using maximum likelihood, evolutionary distance, and maximum parsimony methods. Molecular Biology and Evolution, 28: 27312739. DOI: https://doi.org/10.1093/molbev/msr121

Tomás G, Hernández M, Marandino A, Panzera Y, Maya L, Hernández D, Pereda A, Banda A, Villegas P, Aguirre S et al. (2012). Development and validation of a TaqMan-MGB real-time RTPCR assay for simultaneous detection and characterization of infectious bursal disease virus. Journal of Virological Methods, 185:

101-107. DOI: https://doi.org/10.1016/j.jviromet.2012.06.012

Tsai SM, Liu HJ, Shien JH, Lee LH, Chang PC and Wang CY (2012). Rapid and sensitive detection of infectious bursal disease virus by reverse transcription loop-mediated isothermal amplification combined with a lateral flow dipstick. Journal of Virological Methods, 181: 117-124. https://doi.org/10.1016/j.jviromet.2011.09.002

Van Den Berg TP (2000). Acute infectious bursal disease in poultry: A review. Avian Pathology, 29: 175-194. https://doi.org/10.1080/03079450050045431

Van Den Berg TP, Gonze M and Meulemans G (1991). Acute infectious bursal disease in poultry: Isolation and characterisation of a highly virulent strain. Avian Pathology, 20, 133-143. DOI: https://doi.org/10.1080/03079459108418779

Van Den Berg TP, Gonze M, Morales D and Meulemans G (1996). Acute infectious bursal disease in poultry: Immunological and molecular basis of antigenicity of a highly virulent strain. Avian Pathology, 25: 751-768. https://doi.org/10.1080/03079459608419179

Van Den Berg TP and Meulemans G (1991). Acute infectious bursal disease in poultry: Protection afforded by maternally derived antibodies and interference with live vaccination. Avian Pathology, 20: 409-421. DOI: https://doi.org/10.1080/03079459108418779

Van Den Berg TP, Morales D, Eterradossi N, Rivallan G, Toquin D, Raue R, Zierenberg K, Zhang MF, Zhu YP, Wang CQ et al. (2004). Assessment of genetic, antigenic and pathotypic criteria for the characterization of IBDV strains. Avian Pathology, 33: 470-476. DOI: https://doi.org/10.1080/03079450400003650

Wise MG, Wise MG, Suarez DL, Suarez DL, Seal BS, Seal BS, Pedersen JC, Pedersen JC, Senne D, Senne D et al. (2004). Development of a real-time reverse-transcription PCR for detection of Newcastle disease virus RNA in clinical samples. Journal of Clinical Microbiology, 42: 329-338. DOI: https://doi.org/10.1128/JCM.42.1.329 